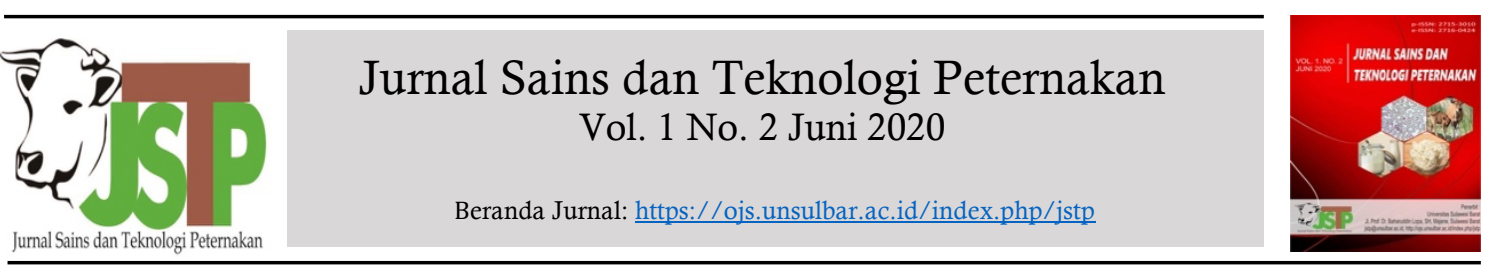

\title{
Paritas dan Body Condition Score (BCS) Ternak Sapi Bali di Wilayah Kanusuang, Sulawesi Barat
}

(The Parity and Body Condition Score (BCS) of Bali Cattle in the Kanusuang Region, West Sulawesi)

Ummul Masir $^{*}$, Santi ${ }^{2}$, Andi Fausiah ${ }^{2}$

${ }^{1}$ Program Studi Agribisnis Peternakan, Politeknik Pertanian Negeri Pangkajene Kepulauan. Jalan Poros Makassar-Pare Pare KM.83, Kec. Mandalle, Pangkep.

${ }^{2}$ Jurusan Peternakan, Fakultas Ilmu Pertanian, Universitas Al Asyariah Mandar. Jalan Budi Utomo No. 2 Manding, Kec. Polewali, Kabupaten Polewali Mandar.

\section{A RTICLE INFO}

Received: 1 Juni 2020

Accepted: 20 Juni 2020

${ }^{*}$ Corresponding author ummulmasir@gmail.com

Keywords:

Bali Cattle

Body Condition Score

Parity

Kanusuang

\begin{abstract}
A B S T R A C T
The study aims to provide an overview of the value of the body condition and parity of Bali cattle in the Kanusuang region, West Sulawesi. A total of $11 \mathrm{Bali}$ cows that have been given birth once were involved in this study. Data were collected by direct observation of Bali cows in the field and interview toward the farmers. All cows were subjected to body condition scoring (BCS; scale 1 - 5) through visual measurement. The results of this study showed that most of the proportion of Bali cattle with parity 1 and 2 were the same, $36,36 \%$, while parity 3 was $27,2 \%$. There were $15,4 \%$ of the total sample observed cattle have BCS value 3 , followed by BCS values 4 and 5 respectively $46,1 \%$ and $38,5 \%$. The correlation test between parity and BCS obtained value $r=0,355(\mathrm{P}>0,05)$ means no correlation between both of the data. The BCS value of livestock belonging to farmers in the study location was in the normal range, which refers to the standard BCS values 1-5. The parity value obtained cannot be used as a standard for determining reproductive performance, but was invented as an evaluation of reproductive efficiency.
\end{abstract}

\section{A B S T R A K}

Penelitian bertujuan untuk memberikan gambaran nilai kondisi tubuh dan paritas ternak induk sapi Bali di wilayah Kanusuang, Sulawesi Barat. Sebanyak 11 ekor induk sapi Bali yang telah beranak sekali menjadi objek dalam penelitian ini. Pengambilan data menggunakan metode observasi dengan pengamatan secara langsung terhadap induk sapi Bali dan wawancara kepada peternak. Pengukuran nilai BCS secara visual dan teknik penilaian BCS menggunakan skala 1-5. Proporsi ternak sapi Bali dengan paritas 1 dan 2 adalah sama yaitu $36,36 \%$, sedangkan paritas 3 sebanyak $27,2 \%$. Terdapat $15,4 \%$ ternak dari total sampling yang diamati memiliki nilai BCS 3, dilanjutkan dengan nilai BCS 4 dan 5 secara berturut-turut adalah $46,1 \%$ dan $38,5 \%$. Uji korelasi antara paritas dengan $\mathrm{BCS}$ diperoleh nilai $\mathrm{r}=0,335(\mathrm{P}>0.05)$ yang memperlihatkan bahwa tidak ada korelasi antara BCS dengan nilai paritas ternak. Nilai BCS ternak milik peternak di lokasi penelitian berada pada kisaran normal yang mengacu pada standar nilai BCS 1-5. Nilai paritas yang diperoleh tidak dapat dijadikan sebagai standar penentuan performa reproduksi, namun sebagai penilaian efisiensi reproduksi.
Kata Kunci:

Body condition score

Paritas

Kanusuang

Sapi Bali
p-ISSN: 2715-3010 | e-ISSN: 2716-0424 


\section{Pendahuluan}

Keberagaman bangsa ternak sapi di Indonesia sebagian besar dipengaruhi oleh persilangan antara ternak sapi tropis seperti sapi zebu (bos indicus) dan ternak sapi sub-tropis yaitu sapi taurine (Bos taurus). Dari jenis tersebut terdapat pula banteng liar (Bos javanicus javanicus) yang didomestikasi di daerah Bali atau Blambangan, Jawa Timur yang kemudian ditetapkan sebagai cikal bakal dari Sapi Bali (Bos javanicus (Martojo, 2012). Ternak sapi Bali merupakan ternak varietas lokal Indonesia yang banyak dikembangkan dan dipelihara oleh peternak di wilayah Timur Indonesia khususnya di daerah Sulawesi Selatan, Bali, Nusa Tenggara Timur (NTT), Nusa Tenggara Barat (NTB), Sulawesi Tenggara, dan Lampung (Sunarto \& Setyawan, 2015).

Sapi Bali memiliki potensi untuk dikembangkan lebih lanjut sebagai ternak potong yang memiliki persentase karkas yang tinggi di mana kandungan dagingnya rendah lemak dibanding dengan Zebu dan Taurin (Sunarto \& Setyawan, 2015). Hal ini didukung oleh kapasitasnya yang mampu beradaptasi pada lingkungan yang kering dan juga memiliki kemampuan untuk mencerna hijauan dengan kandungan nutrisi yang rendah saat memasuki musim kemarau. Berdasarkan keunggulan tersebut, potensi sapi Bali sebagai ternak lokal untuk pemenuhan kebutuhan daging sapi di Indonesia sangat tepat. Akan tetapi, beberapa penelitian menunjukkan bahwa kemampuan reproduksi ternak sapi Bali masih tergolong rendah karena beberapa faktor baik dari lingkungan, manajemen pemeliharaan, ataupun kondisi ternak. Untuk mengkaji hal tersebut, penelitian terkait masih terus dikembangkan hingga saat ini.

Usaha untuk meningkatkan populasi ternak dapat dilakukan melalui peningkatan manajemen tingkat kelahiran di mana nilai ideal kelahiran adalah satu anak per tahun untuk seekor induk. Penampakan performa reproduksi jika dikaitkan dengan efisiensi reproduksi dapat dihitung melalui angka conception rate (CR), calving intercal (CI) dan service per conception (S/C). Adapun berapa kali ternak mengalami partus merupakan sebuah periode yang dihitung dengan nilai Paritas 1 dan seterusnya. Produksi tertinggi umumnya dicapai pada paritas ke empat pada kisaran umur 5,5 - 7 tahun (Makin \& Suharwanto, 2012). Dibutuhkan sebuah usaha di tengah keterbatasan faktor yang dihadapi untuk mencapai angka yang ideal, seperti ketersediaan pejantan di lapangan atau keterampilan inseminator (Saili, 2020). Penilaian ini dapat dilakukan melalui penampakan performa reproduksi yang sangat penting untuk dikaji.

Salah satu faktor yang memengaruhi performa reprodusi ternak sapi Bali adalah BCS yang dilakukan dengan pengamatan visual dan membantu peternak dalam memperoleh gambaran mengenai tingkat cadangan perototan dan perlemakan dalam tubuh. Kandungan lemak yang berlebih cenderung menutupi saluran reproduksi yang berdampak pada terjadinya gangguan fungsi organ-organ reproduksi. Sebaliknya, ternak dengan BCS rendah dapat menurunkan kemampuan tubuh dalam sintesis hormon reproduksi dan gangguan proses ovulasi. Penelitian ini bertujuan untuk memberikan gambaran nilai kondisi tubuh dan paritas ternak induk sapi Bali di wilayah Kanusuang, Sulawesi Barat.

\section{Materi dan Metode}

\subsection{Bahan}

Penelitian ini dilakukan pada 11 ekor ternak sapi Bali betina yang dipelihara secara tradisional di peternakan rakyat Kecamatan Kanusuang, Sulawesi Barat.

\subsection{Metode}

Metode penelitian yang dilakukan adalah metode observasi dengan melakukan pengamatan secara langsung terhadap induk sapi Bali. Penentuan sampel berdasarkan teknik purposive sampling (berdasarkan pertimbangan) ternak berumur di atas 2 tahun dan minimal telah partus satu kali. Ternak dikategorikan pada paritas 1 ( $\mathrm{n}=4$ ekor), paritas 2 ( $\mathrm{n}=4$ ekor), dan paritas 3 ( $n=3$ ekor).

Tahapan persiapan pada penelitian ini dimulai dengan kunjungan ke lokasi peternakan dan mendata jumlah ternak yang berada di wilayah tersebut. Selanjutnya, dilakukan pengumpulan data primer yang bersumber dari wawancara langsung kepada peternak dan inseminator UPTD. Nilai BCS ternak diukur secara visual dan teknik penilaian BCS menggunakan skala 1-5 (Soares \& Dryden, 2011).

\subsection{Analisis Data}

Data ditabulasi di Microsoft excel dan disajikan dalam bentuk grafik secara deskriptif untuk mengetahui persentasi paritas ternak dan nilai BCS induk sapi Bali. Selanjutnya, data diolah menggunakan program SPSS untuk melihat korelasi antara nilai BCS dengan Paritas. 


\section{Hasil dan Pembahasan}

\subsection{Nilai Paritas}

Persentasi ternak sapi Bali dengan paritas 1 dan 2 memiliki proporsi yang sama dalam penelitian ini yaitu $36,36 \%$ dan proposi ternak paritas 3 yaitu $27,2 \%$ dari total ternak yang disampling (Gambar 1). Nilai paritas 1 dan 2 menunjukkan sapi Bali telah melahirkan pertama dan kedua. Adanya perbedaan nilai paritas dalam penelitian ini dipengaruhi oleh potensi ternak yang berbeda disertai dengan ragam umur yang disampling Yusuf et al. (2015) melaporkan bahwa jumlah proporsi ternak tiap paritas berbeda diduga karena tingkat kesulitan ternak untuk bunting bervariasi, sehingga diperlukan upaya untuk memaksimalkan dan meningkatkan potensi reproduksi sapi Bali.

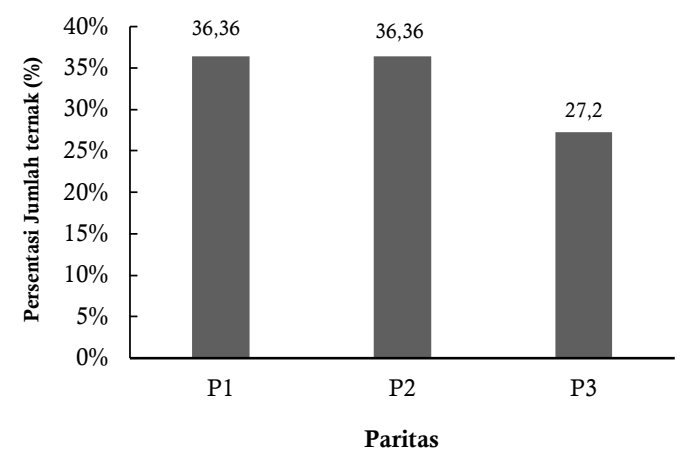

Gambar 1. Penentuan nilai paritas pada induk sapi Bali di wilayah Kanusuang. P1: Paritas 1 (Telah melahirkan sekali), P2: Paritas 2 (Telah melahirkan 2 kali), P3: Paritas 3 (Telah melahirkan 3 Kali).

\subsection{Nilai Paritas}

Nilai BCS ternak sapi Bali pada penelitian ini berada pada kisaran nilai 3 - 5 yang mengacu pada standar pengukuran BCS khusus ternak sapi Bali disajikan pada Gambar 2. Sebesar 15,4 $\%$ dari total ternak yang disampling memiliki nilai BCS 3 di mana penampakan bagian belakangnya rata hingga ke bahu. Terdapat jaringan lunak yang menutup keseluruhan di area bahu juga pada bagian leher. Pangkal ekor nampak datar dengan cekungan yang sangat sedikit. Nampak tulang belakang tertutupi oleh jaringan lunak begitu pun kondisi tulang rusuk (Soares \& Dryden, 2011).

Selanjutnya, nilai BCS 4 dan 5 yang diperoleh secara berturut-turut adalah $46,1 \%$ dan $38,5 \%$. Berdasarkan karakteristiknya nilai BCS 4 ditandai oleh penampakan area belakang agak datar atau sedikit bulat dengan pundak tertutupi oleh jaringan lunak. Tulang belakang akan nampak jika diperhatikan dalam jarak yang sangat dekat. Tulang rusuk tetap nampak meskipun tertutupi oleh jaringan lunak. Daerah gelambir di daerah lipatan leher sudah mulai terlihat. Karakteristik BCS 5 ditandai dengan adanya lipatan lemak di daerah kaki ternak, kaki belakang yang lebih bulat dan penuh. Daerah pundak dan leher tertutup penuh oleh jaringan lunak juga pada bagian pangkal ekor sudah mulai ditutupi oleh jaringan lunak. Tulang rusuk sudah tidak nampak secara jelas disertai lipatan kulit bagian leher yang semakin besar hingga mencapai daerah brisket. Area tulang pinggul masih agak nampak meskipun ditutupi oleh jaringan lunak (Soares \& Dryden, 2011).

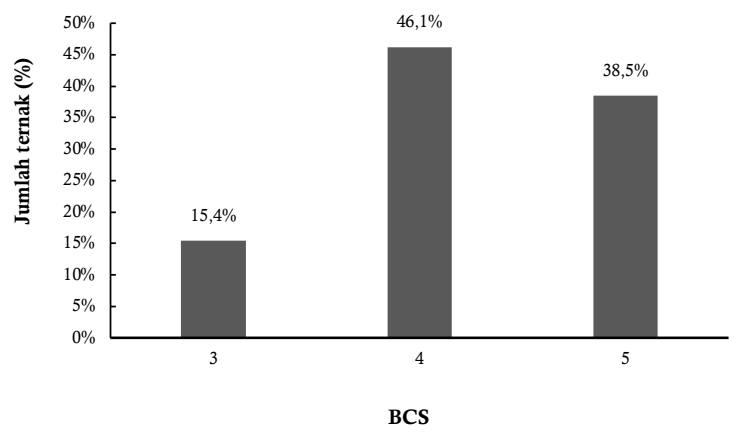

Gambar 2. Nilai BCS (Body Condition Score) pada induk sapi Bali di wilayah Kanusuang.

Berdasarkan data yang diperoleh, nilai BCS ternak milik peternak di lokasi penelitian berada pada kisaran normal jika mengacu pada standar nilai BCS 1-5. Ternak sapi Bali memiliki ciri khas dengan proposi tubuh yang lebih kecil dibandingkan Bos taurus dan Bos indicus, sehingga diperlukan penilaian BCS tersendiri (Soares \& Dryden, 2011).

Perolehan kinerja reproduksi yang efisien dapat dicapai dengan pemberian nutrisi yang baik pada siklus di awal laktasi dan sebelum melahirkan. BCS merupakan cerminan status gizi ternak dalam menyediakan kecukupan cadangan protein dan lemak tubuh yang dapat digunakan secara tiba-tiba. Saat ternak tidak mendapatkan asupan nutrisi yang cukup ataukah ternak berada pada masa laktasi, maka cadangan protein segera dapat digunakan untuk memenuhi kebutuhan energi terlebih saat ternak memasuki periode laktasi untuk menyusui pedet (McCosker, 2015).

Beberapa peneliti menyebutkan bahwa BCS menjadi parameter utama dalam memengaruhi efisiensi reproduksi yang berlaku untuk semua bangsa ternak sapi. Ternak dengan kondisi yang baik memiliki tingkat kebuntingan yang lebih tinggi. Yusuf et al. (2015) melaporkan bahwa penurunan nilai BCS seekor ternak menjadi 
faktor yang berkontribusi terhadap menurunnya performa reproduksi ternak sapi Bali.

Perbedaan nilai BCS untuk tiap-tiap ternak diduga karena adanya perbedaan konsentrasi bovine growth hormone (BGH) atau hormon pertumbuhan sapi yang berperan penting dalam setiap proses fisiologis (Oberbauer, 2015). Hormon pertumbuhan secara langsung ataupun tidak langsung memegang peran penting pada jaringan pertumbuhan dan lemak metabolis yang berkaitan dengan perannya pada kerja reproduksi, laktasi, dan stimulasi pertumbuhan pada hewan (Akçay, Akyüz, \& Bayram, 2015). Suwiti, Besung, \& Mahardika, (2017) melaporkan kadar BGH pada ternak sapi Bali tidak dipengaruhi oleh wilayah ternak dipelihara meskipun konsentrasi BGH lebih tinggi pada pejantan dibandingkan betina.

Dalam hal perbaikan nilai BCS terdapat dua hal yang dapat dilakukan yaitu meningkatkan kualitas pakan melalui pemberian superfood dan memberikan kebutuhan nutrisi sesuai dengan kondisi dan keadaan ternak pada saat itu. (McCosker, 2015). Ukuran tubuh ternak dipengaruhi salah satunya adalah konsentrasi growth hormone $(\mathrm{GH})$ di mana pada sapi Bali Hormon BGH nya tergolong rendah untuk semua ternak yang tersebar di beberapa daerah di Indonesia Timur (Suwiti et al., 2017).

\subsection{Nilai Korelasi Paritas dan BCS}

Uji korelasi antara paritas dengan BCS diperoleh nilai $\mathrm{r}=0,335(\mathrm{P}>0.05)$ yang memperlihatkan bahwa tidak ada korelasi antara BCS dengan nilai paritas ternak. Oleh karenanya, paritas tidak dapat digunakan sebagai salah satu acuan dalam penentuan performa reproduksi ternak sapi Bali meskipun secara numerik terdapat nilai paritas yang tinggi dan rendah. Meskipun demikian, nilai paritas dapat digunakan sebagai gambaran aktualisasi kematangan fisik dari seekor ternak betina (Hadisutanto, Purwantara, \& Darodjah, 2013). Beberapa hasil penelitian yang terdahulu, disebutkan bahwa tidak ada pengaruh nilai paritas terhadap nilai S/C, CR, CvR, CI, DO yang dalam hal ini digunakan sebagai parameter performa reproduksi (Tjatur \& Ihsan, 2011; Wahyudi, Susilawati, \& Wahyuningsih, 2013; Zaiful, Setiatin, \& Harjanti, 2018)

Adapun paritas, menurut Murti (2014) adalah berbanding lurus dengan umur, sehingga semakin tinggi nilai paritasnya maka umur ternak semakin tua dan memengaruhi performa produksi. Secara fisiologis, kondisi tubuh ternak yang tua akan mengalami penurunan kemampuan otot, tulang serta jaringan dan kerusakan sel-sel (Zainudin, Ihsan, \& Suyadi, 2014). Faktor ukuran tubuh juga berperan penting dalam penentuan performa reproduksi. Ukuran tubuh sapi Bali yang umumnya berukuran kecil dipengaruhi oleh sifat genetik dan lingkungan terkait kuantitas dan kualitas pakan yang diberikan (Saili, 2020).

\section{Kesimpulan}

Nilai paritas yang diperoleh belum dapat dijadikan sebagai standar penentuan performa reproduksi, namun dapat dijadikan sebagai penilaian efisiensi reproduksi. Nilai BCS sangat berkaitan untuk menentukan status reproduksi pada induksi ternak sapi Bali.

\section{Daftar Pustaka}

Akçay, A., Akyüz, Bi., \& Bayram, D. (2015). Determination of the AluI polymorphism effect of bovine growth hormone gene on carcass traits in Zavot cattle with analysis of covariance. Turkish Journal of Veterinary and Animal Sciences, 39(1), 16-22.

Hadisutanto, B., Purwantara, B., \& Darodjah, S. (2013). Involusi uteri dan waktu estrus pada Induk sapi perah $\mathrm{FH}$ pasca partus. Jurnal Ilmu Ternak Universitas Padjadjaran, 13(1), 4-7. https://doi.org/10.24198/jit. v13i1.5113

Makin, M., \& Suharwanto, D. (2012). Performa sifat-sifat produksi susu dan reproduksi sapi perah Fries Holland di Jawa Barat. Jurnal Ilmu Ternak Universitas Padjadjaran, 12(2), 39-44. https://doi.org/10.24198/jit.v12i2. 5128

Martojo, H. (2012). Indigenous Bali cattle is most suitable for sustainable small farming in Indonesia. Reproduction in Domestic Animals, 47(1), 10-14. https://doi.org/10.1111/j. 1439-0531.2011.01958.x

McCosker, K. (2015). Improving beef cattle production in free range systems: Implications for Indonesia. Proceeding International Improving Tropical Animal Production for Food Security, 1(1), 55-62. Kendari: Unhalu Press.

Murti, T. W. (2014). Ilmu Manajemen dan Industri Ternak Perah. Bandung: Pustaka Reka Cipta.

Oberbauer, A. M. (2015). Developmental programming: The role of growth hormone. Journal of Animal Science and Biotechnology, 6(8), 1-7. https://doi.org/ 


\subsection{6/s40104-015-0001-8}

Saili, T. (2020). Production and reproduction performances of Bali cattle in Southeast Sulawesi-Indonesia. International Conference: Improving Tropical Animal Production for Food Security, 465. IOP Publishing Ltd. https://doi.org/10.1088/ 1755-1315/465/1/012004

Soares, F. S., \& Dryden, G. M. (2011). A body condition scoring system for Bali cattle. Asian-Australasian Journal of Animal Sciences, 24(11), 1587-1594. https://doi.org/10. 5713/ajas.2011.11070

Sunarto, \& Setyawan, A. D. (2015). Review: Genetic diversity of local and exotic cattle and their crossbreeding impact on the quality of Indonesian cattle. Biodiversitas Journal of Biological Diversity, 16(2), 327354. https://doi.org/10.13057/biodiv/ d160230

Suwiti, N. K., Besung, I. N. K., \& Mahardika, G. N. (2017). Factors influencing growth hormone levels of Bali cattle in Bali, Nusa Penida, and Sumbawa Islands, Indonesia. Veterinary World, 10(10), 1250-1254. https: //doi.org/10.14202/vetworld.2017.12501254

Tjatur, A. N. K., \& Ihsan, M. N. (2011). Penampilan reproduksi sapi perah Friesian Holstein $(\mathrm{FH})$ pada berbagai paritas dan bulan laktasi di ketinggian tempat yang berbeda. Jurnal Ternak Tropika, 11(2), 1-10.

Wahyudi, L., Susilawati, T., \& Wahyuningsih, S. (2013). Reproductive performance of dairy cattle with varity parity in Kemiri Village, Jabung Subdistrict, Malang Regency. Jurnal Ternak Tropika, 14(2), 1322.

Yusuf, M., Rahardja, D. P., Toleng, A. L., Haryani, R., Asja, M. A., Zulkarnaim, \& Sahiruddin. (2015). Body condition score of Bali cows: Its effect on reproductive status. Proceeding International Improving Tropical Animal Production for Food Security, 1(1), 115-121. Kendari: Unhalu Press.

Zaiful, M. A., Setiatin, E. T., \& Harjanti, D. W. (2018). Pengaruh Paritas Terhadap Performa Reproduksi Induk Sapi Friesian Holstein. Prosiding Seminar Nasional Kebangkitan Peternakan III:" Hilirisasi Teknologi Peternakan Pada Era Revolusi Industri 4.0", 50-55. Semarang: Indonesian Society of Animal Agriculture (ISAA).
Zainudin, M., Ihsan, M. N., \& Suyadi, S. (2014). Efisiensi reproduksi sapi perah $\mathrm{PFH}$ pada berbagai umur di CV. Milkindo Berka Abadi Desa Tegalsari Kecamatan Kepanjen Kabupaten Malang. Jurnal IlmuIlmu Peternakan, 24(3), 32-37. 